\title{
Urban streams in Latin America: Current conditions and research needs
}

\author{
Jeymmy M. Walteros ${ }^{1} \&$ Alonso Ramírez ${ }^{2}$ \\ 1. Environmental Sciences Faculty, Universidad Tecnológica de Pereira-Colombia; jeymmy.walteros@utp.edu.co \\ 2. Department of Applied Ecology, North Carolina State University, NC-USA; alonso.ramirez@ncsu.edu
}

Received 18-X-2019. Corrected 07-VIII-2020. Accepted 31-VIII-2020.

\begin{abstract}
Introduction: Latin America is a highly urbanized region, with most of its population living in cities and urban centers. While information about urban streams in Latin America is rather limited, streams are expected to experience similar environmental impacts and conservation issues as urban streams in parts of the globe, including habitat loss, channelization, sewage discharge, trash, and loss of riparian habitats. Objective: We surveyed a network of researchers from approximately $80 \%$ of the countries in Latin America to obtain information on the condition, state of knowledge, and threats to urban streams in the region. Methods: Most participants were reached via the Macrolatinos@ network (www.macrolatinos.net). Results: We obtained 104 responses from researchers in 18 of the 23 Latin American countries. Most urban streams are impacted or degraded, and inputs of contaminants and wastewater discharges were considered major drivers of stream degradation. Most respondents indicated that stream channelization is common, with some streams completely channelized or buried. Sewage and rainfall runoff management were identified as a major factor degrading streams, with most respondents suggesting that streams are a primary destination for wastewater discharge, much of which is untreated. Major limitations to urban stream conservation in Latin America are the result of limited ecological knowledge, lack of citizen interest or political will to protect them. There are isolated efforts to restore urban streams and riparian zones, but these are initial steps that need further development. Conclusions: Our research network of Latin American scientists proved to be a valuable tool to assess a large number of urban rivers in a relatively understudied region. Urban streams in Latin America face a diversity of stressors and management challenges, and we propose three areas that would benefit from further research to improve our understanding and management of these systems: (1) Studies should focus on the watershed, rather than isolated reaches, (2) researchers should strive to attain a better understanding of ecosystem function and the services provided by urban streams to justify management and restoration efforts, and (3) studies that integrate economic models where downstream users pay for upstream protection and restoration could prove beneficial for many Latin American cities in attempting to address water conservation issues.
\end{abstract}

Key words: Management strategies; quality conditions; scientific knowledge; urban ecosystems; water management; water supply.

Walteros, J.M., \& Ramírez, A. (2020). Urban streams in Latin America: current conditions and research needs. Revista de Biología Tropical, 68(Suppl. 2), S13-S28.

Urban land cover continues to increase around the globe, affecting economic development, energy consumption, natural resource use, and human well-being (McDonald et al., 2014; Romulo et al., 2018). All regions of the planet are expected to continue experiencing increases in urban land use and in urban population density (Montgomery \& Elimelech,
2007; McDonald et al., 2011). Urban areas can have many negative effects on the environment, adding particular pressure on water resources (Vörösmarty, Lévêque \& Revenga, 2005; Vörösmarty, et al., 2010; Seto, Parnell \& Elmqvist, 2013; Rodríguez et al., 2020). Urban water demand requires access to large volumes of clean water, which are often located a long 
distance from the point of consumption. Many streams and rivers are dammed, and aquifers pumped to supply water to cities (Lee, 2000; Romulo et al., 2018). At the same time, wastewater has to be collected, piped, and disposed outside city boundaries, often into water bodies, adding pressure and deteriorating freshwater ecosystems (Da Cruz \& Ríos-Touma, 2018; Ríos-Touma \& Ramírez, 2019). Consequently, many urban streams are degraded and no longer provide many of their valuable ecosystem services (Wade, 2012; Bremer et al., 2016; Fernandez, 2017; Romulo et al., 2018).

Latin America is a highly urbanized region. Since the $1960 \mathrm{~s}$, more than $50 \%$ of its population live in urban areas (Montgomery \& Elimelech, 2007). Today, over $80 \%$ of the population lives in cities of 20000 or more inhabitants, making Latin America more urban than western Europe (Rodríguez \& Martínez, 2008; Koop \& van Leeuwen, 2017; Romulo et al., 2018; Rodríguez et al., 2020). As a whole, Latin America has abundant water resources; yet they are unevenly distributed. While some of these urban areas are experiencing increases in water scarcity, others are facing the challenges of excess precipitation (e.g., flooding, landslides). These dynamics add pressures to stream ecosystems, as they are sources and recipients of urban water demands (Lee, 2000; Fernandez, 2017; Ríos-Touma \& Ramírez, 2019). Stream conservation in the region requires appropriate management strategies to protect sources of water and effectively manage streams receiving wastewater. Most urban areas in Latin America lack legal commitments or resources allocated to protect streams (McDonald et al., 2011; Noyola et al., 2012; McDonald \& Shemie, 2014; Tellman et al., 2018). Although we still have limited knowledge of streams in urban areas of Latin America, we expect most to be degraded.

Our understanding of how urbanization impacts streams in developing countries is limited (Capps, Bentsen \& Ramírez, 2016; Romulo et al., 2018). In general, it is expected that streams respond to urban impacts as described in the urban stream syndrome (Walsh et al., 2005; Roy et al., 2016). In general, urban streams have altered channel geomorphology and hydrology, increased loads of nutrients and contaminants, and reduced populations of native species. Though these predictions are likely to hold true in many urban streams in Latin America, studies suggest that there are important exceptions. For instance, in Puerto Rico, urban streams appear to be as flashy as rural ones and maintain their native fish and shrimp fauna (Ramírez et al., 2009; GutiérrezFonseca \& Ramírez, 2016). There is a diversity of climates in Latin America and cities are located at many elevations, from coastal to mountain areas. Furthermore, there is rapid urban sprawl in many regions and urban infrastructure often lags behind urban growth. Both factors may impact the structure and function of urban streams. Still, urban streams in Latin America provide numerous ecosystem services to those living in their proximity. They move wastewater and trash away from populated areas and they also provide cooling from urban heat, materials for construction (e.g., sand and gravel), and in some cases are food sources (e.g., fish and shrimps). Understanding urban streams as ecosystems should be a priority in this region (Capps, Bentsen \& Ramírez, 2016).

In this study, we attempted to assess the condition of urban streams in Latin America, from Mexico to Argentina and the Caribbean basin, by surveying a network of experts. Specifically, we contacted stream and aquatic fauna experts from each country in Latin America to characterize stream conditions in urban areas and identify major threats to urban stream ecosystems. By focusing on all Latin American countries simultaneously, we attempted to create a realistic picture of the current state of urban streams in the region. The results of this study should aid in identifying research needs and avenues to aid in the protection and restoration of stream ecosystems within urban areas.

\section{MATERIAL AND METHODS}

Our focal area was Latin America as a whole, including Mexico, Central America, 
the Caribbean, and South America. Most countries in the region have populations that are mostly concentrated in urban areas, with more than $80 \%$ of their population considered urban (Ezquiaga, 2015; UN, 2019). The region has a wide variety of climates and hydrologic conditions, from dry to extremely wet environments. Urban areas are equally diverse in size, ranging from small cities (e.g., Nombre de Dios-Durango (Mexico) with 6000 inhabitants and Kourou (Guayana Francesa) and Jalpan de Serra (Mexico) cities with 25000 inhabitants) to large metropolitan centers (e.g., Rio de Janeiro (Brasil) with 12800000 inhabitants and Ciudad de Mexico with 8854600 inhabitants) (Table 1)

We designed a 14-question survey on urban streams in the region (Appendix 1). The survey took approximately 15 minutes to answer and requested that the respondent focused on a single river, familiar to her/him, within an urban center. Questions gathered information on the bio-physical condition of the river, the characteristics of the city, and information on the respondent's expertise.

We used the Macrolatinos@ network (www.macrolatinos.net) to reach people from all countries in Latin America and from more than one city per country. Additional requests were submitted to obtain representation from the entire region. The survey was made available using Google forms during 2014 - 2015, with additional answers added during 2019 to increase the number of countries represented. Multiple choice answers were tallied and analyzed based on frequencies. Narrative answers and comments were read and included as observations by respondents. Additional information on specific urban areas was obtained by conducting a literature review on urban streams in Latin America and the Caribbean.

\section{RESULTS}

We obtained 104 answers to the survey, from researchers in 18 of the 23 Latin American countries (Fig. 1, Table 1). The five countries that were not represented in the answers were:
Haiti and the Dominican Republic from the Caribbean, Belize from Central America, and Suriname and Paraguay from South America.

Representatives from 64 cities, some from the same country, responded to the survey. Mexico was the best represented with 14 cities, followed by Colombia with 10, Costa Rica with 6, and Ecuador, Venezuela and Argentina with 5 each. Cities ranged in size and 13 of the 64 are considered large cities, with over a million inhabitants (Table 1).

Responses came from researchers (37\%), students $(26.5 \%)$, and professors $(21 \%)$. The remaining answers were provided by independent consultants, technicians, and other professionals.

All responses classified urban streams as impacted or degraded, and $99 \%$ of the answers stressed that impacts were considerable (Fig. 2 ). Of them, $36 \%$ considered the impacts as intermediate, with urban streams receiving various amounts of contaminants and discharges. An additional $63 \%$ of the answers indicated more extreme impacts, with streams receiving sewage and other discharges that were evident from the odors emitted by the channel (Fig. 2A).

Physical and geomorphological alterations are also common characteristics of urban streams. In $22 \%$ of the cases, urban streams were described as maintaining natural or almost natural channels with some riparian vegetation present (Fig. 2B). Most answers $(63 \%)$ indicated mixed impacts, with urban streams having part of their channels in more natural conditions, while other sections were heavily engineered. Concrete-lined channels were reported for $15 \%$ of the cases (Fig. 2B).

Most cities have networks of sewage lines to collect discharges from houses and move them to centralized points; only $7 \%$ of the answers mentioned septic tanks as a sewage management option (Fig. 2C). Wastewater infrastructure is not always established in conjunction with wastewater treatment. Fortyeight percent of the responses indicated that untreated wastewater was directly piped into streams. An additional 26\% mentioned the 


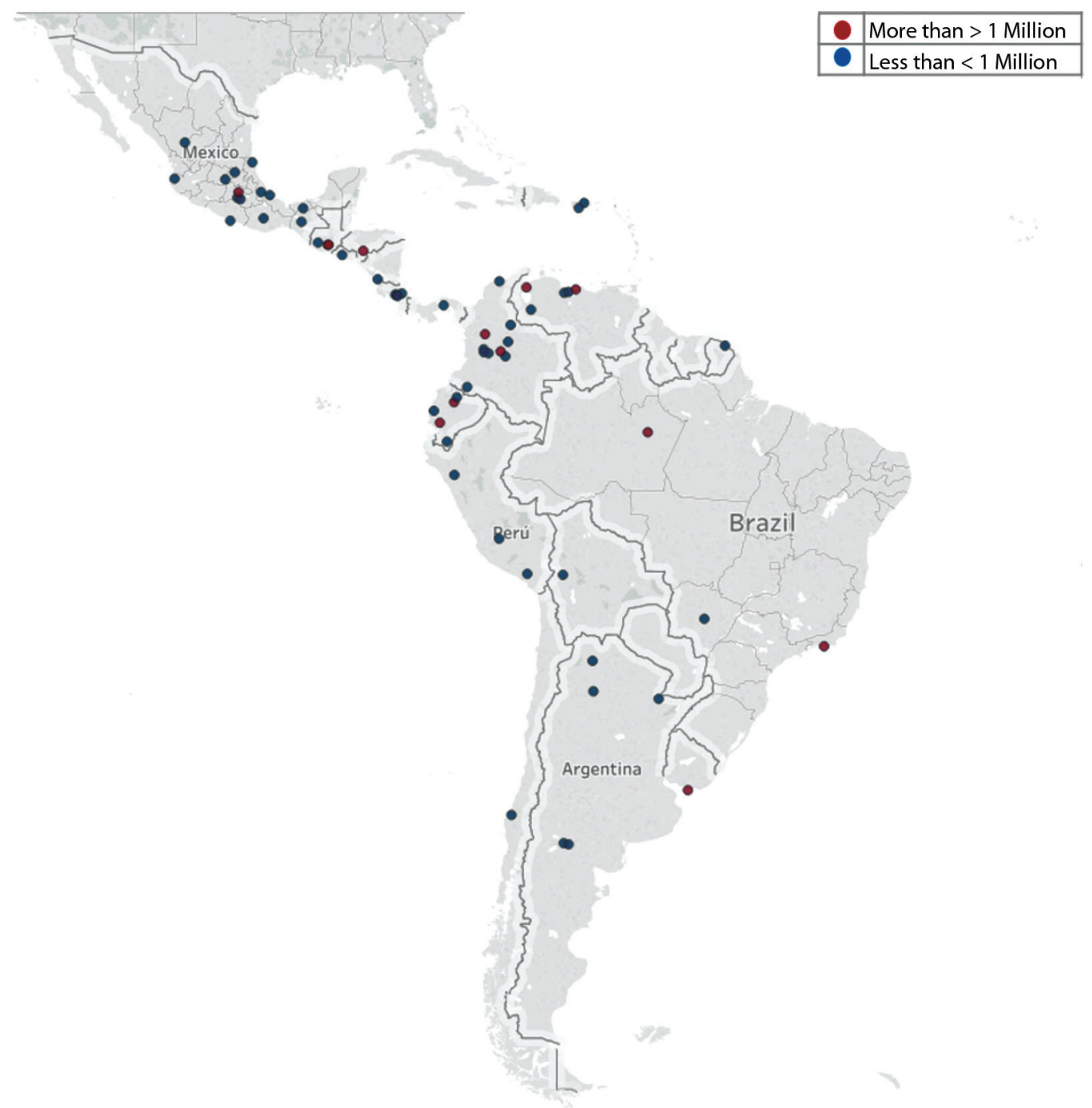

Fig. 1. Latin American cities (approximate location) included in our study, based on answers from survey participants. Map source: Tableau software 2019. Support for research group EIS-UTP.

TABLE 1

Population of major Latin American cities for 2019

\begin{tabular}{lll}
\multicolumn{1}{c}{ COUNTRY } & \multicolumn{1}{c}{ CITY } & POPULATION (per millions) \\
More than $>\mathbf{1}$ Million & & \\
Brasil & Manaos & 2407300 \\
& Río de Janeiro & 6476600 \\
Colombia & Bogotá & 8080700 \\
& Medellín & 2723850 \\
Ecuador & Guayaquil & 2700000 \\
& Quito & 1980000 \\
\hline
\end{tabular}


TABLE 1 (Continued)

\begin{tabular}{|c|c|c|}
\hline COUNTRY & CITY & POPULATION (per millions) \\
\hline \multirow[t]{2}{*}{ Guatemala } & Ciudad de Guatemala & 2450000 \\
\hline & Mixco & 1300000 \\
\hline Honduras & Tegucigalpa & 1160000 \\
\hline México & Ciudad de México & 8854600 \\
\hline Uruguay & Montevideo & 1381200 \\
\hline \multirow[t]{2}{*}{ Venezuela } & Caracas & 2082100 \\
\hline & Maracaibo & 1653200 \\
\hline \multicolumn{3}{|c|}{ Less than $<1$ Million } \\
\hline \multirow[t]{5}{*}{ Argentina } & Ciudad de General Roca & 120000 \\
\hline & Ciudad de Neuquén & 551000 \\
\hline & Ciudad de Resistencia & 416000 \\
\hline & San Salvador de Jujuy & 335300 \\
\hline & San Miguel de Tucumán & 864700 \\
\hline Brasil & Campo Grande & 842300 \\
\hline Bolivia & La Paz & 798000 \\
\hline \multirow[t]{8}{*}{ Colombia } & Armenia & 299700 \\
\hline & Bucaramanga & 528500 \\
\hline & Ibagué & 564100 \\
\hline & Pasto & 450600 \\
\hline & Pereira & 474300 \\
\hline & Santa Marta & 499400 \\
\hline & Tunja & 195500 \\
\hline & Villavicencio & 506000 \\
\hline Chile & Concepción & 766100 \\
\hline \multirow[t]{6}{*}{ Costa Rica } & Cartago & 148000 \\
\hline & Heredia & 138500 \\
\hline & San José & 340000 \\
\hline & San Pedro & 23400 \\
\hline & Siquirres & 31500 \\
\hline & Vázquez de Coronado & 63000 \\
\hline \multirow[t]{3}{*}{ Ecuador } & Loja & 170300 \\
\hline & Otavalo & 39400 \\
\hline & Portoviejo & 206700 \\
\hline Guatemala & Quetzaltenango & 225000 \\
\hline Guyana Francesa & Kourou & 27000 \\
\hline \multirow[t]{13}{*}{ México } & Acapulco & 708100 \\
\hline & Coatepec & 80000 \\
\hline & Cuautla & 154358 \\
\hline & Cuernavaca & 350000 \\
\hline & Jalpan de Serra & 25550 \\
\hline & Tuxtla Gutiérrez & 585400 \\
\hline & Nombre de Dios & 5300 \\
\hline & Oaxaca de Juárez & 255100 \\
\hline & Puerto Vallarta & 203342 \\
\hline & Santiago de Querétaro & 642100 \\
\hline & Tampico Alto & 297284 \\
\hline & Veracruz & 434800 \\
\hline & Villahermosa & 351300 \\
\hline
\end{tabular}


TABLE 1 (Continued)

\begin{tabular}{llc}
\multicolumn{1}{c}{ COUNTRY } & CITY & POPULATION (per millions) \\
Nicaragua & Rivas & 42350 \\
Panamá & Ciudad de Panamá & 477328 \\
Perú & Arequipa & 869400 \\
& Cajamarca & 226000 \\
El Salvador & Ayacucho & 180800 \\
Puerto Rico & San Salvador & 568000 \\
& Ponce & 145278 \\
Venezuela & San Juan & 347052 \\
& Mérida & 238244 \\
& Valencia & 888109 \\
& Maracay & 419052 \\
\hline
\end{tabular}

Source: http://data.un.org/Data.aspx?d=POP\&f=tableCode:240

http://population.city/ \& UN-(2017)
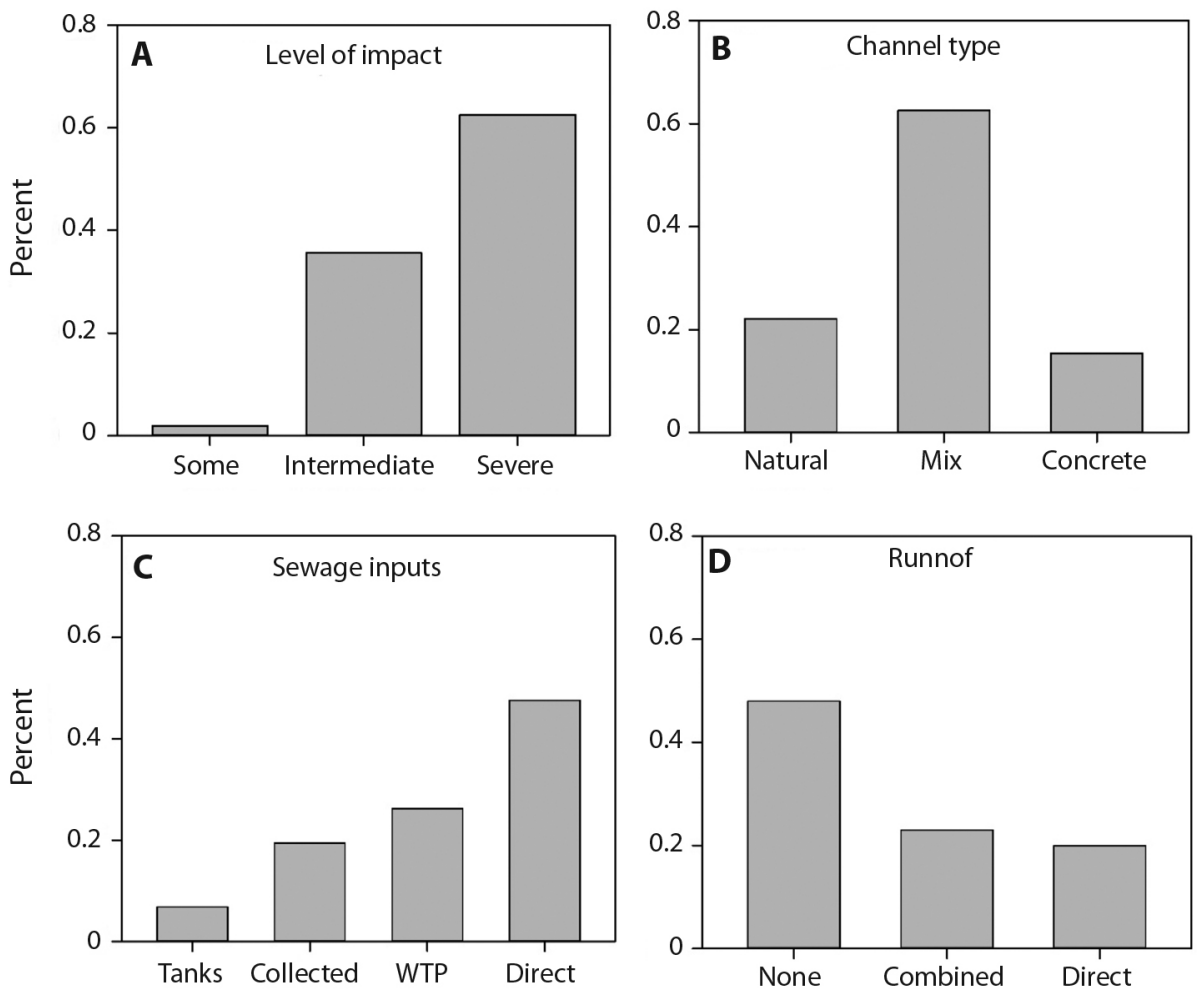

Fig. 2. Assessment of urban stream conditions in Latin America based on the responses provided to the survey. A) Overall condition of urban streams. B) Degree of channel alteration, natural refers to heterogeneous channel substrates and concrete to complete concrete lining of the channel. C) Management of sewage: Tanks refers to Septic tanks, collected refers to city-wide sewerage systems, WTP are water treatment plants, and direct indicate the percent of streams receiving direct discharges. D) Rainfall runoff management, combined refers to combine sewage and runoff systems, direct indicate direct discharges into streams. 
presence of water treatment plants in their cities, while an additional $20 \%$ indicated that sewage is discharged into rivers outside the urban area without considerable treatment (Fig. 2C).

The management of rainfall runoff is also limited. Most survey responses suggested there was a lack of runoff management (Fig. 2D), suggesting water will eventually move over urban surfaces toward low elevation areas and into streams. In those cases, urban runoff freely moves trash and contaminants to streams. The remaining answers indicated different degrees of runoff collection and piping into city-wide systems. In some cities, runoff and sewerage systems are combined ( $23 \%$ of the answers), while in others, runoff is collected and piped directly into urban streams (Fig. 2D).

Questions focused on understanding how much information is available about urban streams resulted in more evenly split answers. Respondents answered that there is information available, but also that there is a clear lack of political will and of funding to study and manage urban streams (47\% of the answers). In contrast, another group of answers (44\%) highlighted the need to conduct further research to understand urban stream ecosystems and their services.

According to survey results, urban streams in Latin America appear to have limited uses for people. Most respondents reported that urban streams are viewed as dangerous due to flooding probability $(56 \%)$, or due to human safety $(13 \%)$, with only an $11 \%$ mentioning their potential for recreational use. They are also viewed as areas to discharge wastewater and dispose of trash (63\% of the answers). Only $8 \%$ percent of the answers mentioned urban streams as sources of water for the community and $5 \%$ mentioned streams as sources of materials (sand and gravel). A small percentage (10\%) mentioned other uses, including recreation, fishing, and irrigation.

Laws and regulations appear to be in place in most countries or cities to protect urban streams, but most respondents state that enforcement is limited. A majority of respondents $(\sim 60 \%)$, answered that sufficient legislation is in place to protect urban waters, with the remaining $40 \%$ reporting insufficient regulations.

In response to questions about the availability of biological or scientific information on stream ecosystems, most respondents mentioned that there is limited information, with $31 \%$ reporting that there is a complete lack of information. When information is available, most of it is focused on species inventories of flora and fauna, with some studies providing information of species diversity (16\% of the answers). Comparatively, information on urban stream ecosystem function is very limited (16\% of the answers). An additional $24 \%$ of the answers highlighted the presence of exotic species in urban streams as a potential conservation problem.

Management, conservation, or restoration efforts are present in $56 \%$ of the cities represented in the survey. Most of those activities are coordinated by the local or national government, but there is also a general consensus that activities are not sufficient or not well coordinated. Some of the respondents mentioned that activities are mostly focused on riparian areas, modification of the stream channel, or maintenance of infrastructure (e.g., dams). Few answers mentioned activities with community participation and those were mostly cleaning campaigns to pick up trash.

\section{DISCUSSION}

\section{Current status of urban streams in Latin America}

According to expert opinion, urban rivers in Latin America are severely degraded and in need of protection and restoration. Our findings suggest this is primarily due to their ubiquitous use as a method to dispose of wastewater and the limited financial resources to support wastewater infrastructure and treatment. In general, urban streams seem to conform to characteristics associated with the urban stream syndrome even though most studies have focused on 
streams in higher-income economies (Walsh et al., 2005; Roy et al., 2016). Urban streams in Latin America are characterized by altered channel morphology (e.g., channelization), inputs of pollutants and sewage, and altered hydrology due to the rapid movement of runoff into streams, indicating that urbanization is affecting Latin American streams similar to streams in other regions of the globe (Romulo et al., 2018; Tellman et al., 2018). Although our survey of researchers in Latin America provides a coarse scale picture of the current status of rivers in the region, the results agree with previous studies that focused on specific cities or regions. For example, various reviews of superficial waters in Latin America (e.g., Noyola et al., 2012 in six country in Latin America and Ramírez-Sánchez, Doll \& Bandala, 2015 in Central America) stress limitations in sewage treatment. Severe urban impacts have been reported for Mexico City and its greater metropolitan area (Bezaury, et al., 2017; García-Sánchez \& Güereca, 2019), Bogota (Alfonso \& Pardo, 2014; Peña-Guzmán, Melgarejo \& Prats, 2016), and Costa Rica (Bower, 2014; Mena-Rivera et al., 2018). As urban sprawl continues to increase in Latin America, freshwater resources will continue to degrade and lose their value as sources of ecosystem services to humans (Lee, 2000; McDonald et al., 2011; Wade, 2012; McDonald et al., 2014; Tellman et al., 2018; Rodríguez et al., 2020).

Complete channelization is typical in urban areas, so much that several natural rivers features are disappearing entirely from urban landscapes (Bremer et al., 2016; Anim et al., 2019). However, we found that most of the urban rivers evaluated by respondents had mix levels of channelization, with sections still draining channels with natural substrate and some riparian vegetation. Channel alterations are common in urban areas, addressing specific issues related to flood control or with maximizing land use (Lee, 2000; Paul \& Meyer, 2001; de Jesús-Crespo \& Ramírez, 2010). Alterations associated with channelization are diverse, involving decreases in channel sinuosity, changes in geomorphology, and in streambed particle composition (Chin, 2006; Anim et al., 2019). These impacts have consequences for stream ecosystems, as increases in rates of streamflow and the transport of particles render streams less retentive and less efficient in processing materials (e.g., organic matter, nutrients) in a given reach (Lepori et al., 2005). Another major consequence of channel alteration is habitat loss and subsequent changes in biodiversity (Paul \& Meyer, 2001; Roni, Hanson \& Beechie, 2008; Vörösmarty et al., 2010; Roy et al., 2016; Ríos-Touma \& Ramírez, 2019). Our understanding of channelization in urban areas and its impacts on tropical stream ecosystems remains limited. However, studies in Puerto Rico have highlighted the importance of natural channels in maintaining urban stream biodiversity (Ramírez et al., 2012; GutiérrezFonseca \& Ramírez, 2016). Native fishes and shrimp are relatively tolerant to urban impacts associated with altered flow regimes, increases in water pollution, and introduced species. However, complete channelization (e.g., concrete channels) results in a complete extirpation of native fauna and the proliferation of invasive species in urban streams (Engman \& Ramírez, 2012).

Direct discharges of sewage and other untreated wastewater into urban streams are major cause of degradation in all Latin American countries (Lee, 2000; Rodríguez \& Martine, 2008; Noyola et al., 2012; Tellman et al., 2018; UN, 2019; Rodríguez et al., 2020). Our findings indicate that there is a wide range of management strategies for dealing with sewage in the area, ranging from household septic tanks to city-wide sewerage collection and water treatment plants. Large metropolitan areas have the most developed systems, connecting all buildings via city-wide sewage systems that discharge at a reduced number of point sources. However, wastewater treatment prior to discharge is still limited (Lee, 2000; Noyola et al., 2012; UN, 2019). This is the case for San José and the larger Metropolitan Area of Costa Rica, where $68 \%$ of the urban population is served by municipal systems (Brower, 2014), but only $8 \%$ of the collected sewage is treated before 
being discharged into rivers (Mena-Rivera et al., 2018). On the bright side, ongoing projects by the Costa Rica water authority will improve this situation in the near future by adding treatment facilities (Alfaro et al., 2017).

Urban and population growth complicate stream ecosystem protection, as growth often outpaces the development of new infrastructure in Latin America. In Bogota, Colombia, a single water treatment plant receives $60 \%$ of all residual waters from the city, highlighting the stress that urban growth has over current infrastructure (Rodríguez et al., 2008; Alfonso \& Pardo, 2014; Peña-Guzmán et al., 2016). Sewage discharges cause major alteration to stream ecosystems, mostly related to the large amounts of organic matter, nutrients, and contaminants entering streams (Rodríguez et al., 2020). Studies in urban streams in Puerto Rico provide an example of how ecosystems recover once inputs of sewage are removed. Although sewage inputs are still present, most are treated at water treatment plants and do not enter streams (Ramírez et al., 2012). Streams draining the Metropolitan Area of San Juan are polluted, but native fish and shrimp are able to colonize those streams and their population densities remain similar to those found in rural rivers (Ramírez et al., 2009).

The large proportion of impervious surface cover in urban areas considerately limits rainfall infiltration, increasing runoff and stream flashiness, as water level increases soon after rainfall (Walsh et al., 2005; Roy et al., 2016). Management of urban runoff is critical to limit deviation from the natural flow regime and avoid stream ecosystem alteration (PeñaGuzmán et al., 2016). Our findings indicate that urban runoff undergoes minimal management in Latin America, most often runoff directed into nearby streams. Worst-case scenarios occur in urban areas that combine sewage and runoff systems that increase sewage pollution during storms (Brower, 2014; Mena-Rivera et al., 2018; Rodríguez et al., 2020).

Green infrastructure projects may help to reduce runoff and protect streams. This type of management strategy is becoming popular in
Latin America, with examples from cities like Bucaramanga (Colombia), Maracaibo (Venezuela), Quito (Ecuador), Tegucigalpa (Honduras) and San Juan (Puerto Rico) (Tellman et al., 2018). Runoff impacts stream ecosystems via two main mechanisms: by altering the natural flow regime and by transporting pollutants (Peña-Guzmán et al., 2016). Urban hydrology is characterized by rapid changes in discharge following rainfall events, with floods lasting shorter periods of time, relative to rural and forested watersheds (Walsh et al., 2005). Increases in flashiness create adverse conditions for stream fauna and increase particle transport. Along with changes in hydrology, runoff moves pollutants from the urban watershed to the streams, increasing impacts on ecosystems. Urban runoff chemistry is characterized by containing a diversity of components, perhaps best described as "chemical cocktails" (Kaushal et al., 2018) that have a variety of impacts on stream ecosystems ( $\mathrm{Da}$ Cruz \& Ríos-Touma, 2018).

\section{Major challenges and limitations for science and conservation}

Major limitations to urban stream conservation in Latin America are associated with our limited knowledge of their value, which partially accounts for the lack of citizen interest and political will to protect them. As is the case for most tropical ecosystems, our understanding of diversity, function, and the ecological services provided by urban streams is rather limited. According to our survey, there is a basic knowledge of urban stream biodiversity and environmental characteristics (e.g., physical and chemical characterizations), but we lack in-depth knowledge of ecosystem function and services (Vörösmarty et al., 2010; Ríos-Touma \& Ramírez, 2019). Even so, a relatively large proportion of answers to our survey stressed that there is enough information available to warrant urban stream conservation, even when this information might come from few case studies. Urban streams provide key ecosystem services, such as flood mitigation, 
recreation, cultural, urban temperature buffering, among others (Corcoran et al., 2010; Wade, 2012; Elmqvist et al., 2013; MartínOrtega et al., 2013; Fernández, 2017; Romulo et al., 2018). According to our survey, in Latin America, urban streams provide a variety of services, including fishing, recreation, gravel and sand mining, and in some cases, even water supply for irrigation. A better understanding of the value and services provided by urban stream in Latin America is necessary for their conservation.

Most tropical countries lack legislation to protect urban rivers or, if present, lack appropriate enforcement (Ramírez, Pringle \& Wantzen, 2008; Noyola et al., 2012; Peña-Guzmán et al., 2018). Our survey provides a similar picture: a high proportion of respondents emphasized that lack of enforcement is the main factor responsible for urban stream degradation. Some responses indicated the presence of a variety of regulations, pointing to specific pieces of legislation, which are not applied in their cities. Mexico, Colombia, Brasil, Argentina and Peru are examples of countries with strong water legislation and management policies that are relatively recent and should be enforced in the near future (Akhmouch, 2012). It is likely that part of the reason for the lack of enforcement is related to a lack of appreciation or value of the services provided by urban streams. This situation might improve with the availability of new tools developed in academia that help us understand the urban water cycle and facilitate decision making by local governments (PeñaGuzmán et al., 2018; Fernandez, 2017).

\section{On-going efforts to improve urban streams}

There are rays of hope for urban streams in Latin American, with some cities making clear efforts toward improving or restoring them. Efforts are often local, some related to improving safety from flooding or landslides, and others focusing on recreation and promoting the development of urban parks, walk or bike paths. These trends were observed in our survey, with participants mentioning that efforts to manage, protect, or restore urban streams are limited and localized. Still, restoration projects are improving conditions for certain streams and represent examples that could be emulated in other urban areas. The city of Quito, Ecuador, offers a case study that highlights the importance of involving local communities to maximize the success of restoration projects. Da Cruz and RíosTouma (2018) contrasted restoration projects in Quito conducted by the government with limited consultation of local neighbors and restoration projects designed and developed with major community participation. Projects with major community participation were clearly the best alternative and the most successful. Similarly, community involvement was also pivotal in the restoration of Quebrada Chiclana, in the headwaters of the Rio Piedras watershed in Puerto Rico. The stream was completely buried by developers using a French drain and its restoration was possible after long litigation by downstream communities concerned with erosion and safety for their homes (Roni, Hanson \& Beechie, 2008; Lugo et al., 2011; Manrique-Hernández et al., 2016; Fernandez, 2017; Romulo et al., 2018; Anim et al., 2019).

Our research network of Latin American scientists proved to be a valuable tool to assess a large number of urban rivers quickly (e.g., de Jesús-Crespo \& Ramírez, 2010; GutiérrezFonseca \& Ramírez, 2016; Da Cruz and RíosTouma, 2018). While the information collected is basic, it highlights the value of networking to tackle complex topics, like the status of urban rivers in such a large region. Macrolatinos@ (www.macrolatinos.net) is a network of researchers and students working with freshwater ecosystems in Latin America. The survey shared with the network was composed of simple questions to reduce possible biases related to the expertise of the respondent. Thus, we feel confident that our findings are an accurate reflection of stream conditions in urban streams in the region. We are planning further studies to explore specific components of urban streams in the region, in collaboration with the network. The interest expressed by participants 
is a positive indicator that researchers value urban streams and are interested in understanding their dynamics to inform management of freshwater resources in Latin America.

\section{Future directions}

Urban streams in Latin America face a diversity of stressors and management challenges. Based on available published information and results from our survey, we propose three areas that would benefit from further research to improve our understanding and management of urban streams in Latin America.

Studies should focus on the watershed, rather than isolated urban reaches. Given that urban areas are often located in the lower reaches of a watershed, many have relatively less impacted or even natural headwaters. A focus on the watershed as a whole is likely to improve management practices directed toward conservation and risk management. Most flooding in lowlands can be associated with headwater deforestation or urbanization. Thus, risk reductions could be achieved by managing watershed components, rather than by channelizing urban reaches.

Urban stream should be studied as components of the urban socio-ecological system. Streams are integrated within their urban landscapes and are affected by socio-economic and political decisions associated with the management of urban systems. Our understanding of the dynamics of urban streams would benefit from information about how they are affected by socio-economic factors.

A better understanding of ecosystem function and the services provided by urban streams will likely help in justifying their management, conservation, and restoration. Our knowledge of how urban streams function is rather limited and is based on isolated examples from specific geographic areas. Increasing the geographic scope of our urban stream studies will help improve strategies for ecosystem management and conservation. At the same time, improving our understanding of the services we receive from urban streams (e.g., urban cooling, recreation) may help justify their protection. The use of economic models where downstream users pay for upstream conservation, protection, and restoration, could prove beneficial for the management of water resources in Latin American cities.

Ethical statement: authors declare that they all agree with this publication and made significant contributions; that there is no conflict of interest of any kind; and that we followed all pertinent ethical and legal procedures and requirements. All financial sources are fully and clearly stated in the acknowledgements section. A signed document has been filed in the journal archives.

\section{ACKNOWLEDGEMENTS}

This study was possible thanks to the collaboration of many Latin American researchers and the Macrolatinos@ network. We thank Augustin Engman and Juan Castaño for his comments on the manuscript and to the EISUTP group for aid in designing the map in figure 1. AR was funded by the National Science Foundation, grant DEB-1938843.

\section{RESUMEN}

Corrientes urbanas en América Latina: condiciones actuales y necesidades de investigación. Introducción: Latinoamérica es una región altamente urbanizada, con la mayoría de su población viviendo en ciudades y centros urbanos. Es bastante limitada la información sobre los ríos urbanos en esta región, sin embargo, se reconocen algunas problemáticas ambientales sobre estos ecosistemas urbanos, los cuales suelen ser similares en toda la región. Algunas de estas son la pérdida de hábitat, la canalización, la descarga de aguas residuales, la basura y la pérdida de zonas ribereñas. Objetivo: Nuestro propósito es obtener información sobre la condición, el estado del conocimiento y las amenazas de nuestros ríos urbanos en Latinoamérica. Métodos: Para esto se compartió una encuesta entre investigadores de la región, contactados en su mayoría a través de la red Macrolatinos@ (www.macrolatinos.net). Resultados: Se recibieron 104 respuestas de personas en 18 países, de los 23 que conforman Latinoamérica. La mayoría de los ríos urbanos se encuentran degradados, principalmente por los aportes de contaminantes y la descarga de aguas residuales. Existen ríos que han sido canalizados 
completamente, sin embargo, otros presentan algunos tramos con estructuras duras y muy pocos muestran una condición natural. El manejo de las aguas residuales y de la escorrentía de lluvias se identificaron como un factor importante en estos ríos. Es común encontrar sistemas combinados de alcantarillado y escorrentía de lluvias, que finalmente se mezclan y llegan a los ríos sin un tratamiento considerable. Las principales limitaciones para la conservación y restauración de los ríos urbanos en Latinoamérica es la falta de conocimiento ecológico, el desinterés del ciudadano y la falta de voluntad política. Aunque existen esfuerzos aislados que viene trabajando por restaurar tanto los ríos como las zonas ribereñas, estos son pasos iniciales que necesitan un mayor desarrollo. Conclusiones: Nuestra red de investigación de científicos latinoamericanos demostró ser una herramienta valiosa para evaluar una cantidad de ríos urbanos de forma rápida y precisa. Nuestros ríos enfrentan una serie de impactos estresantes, por lo que requieren urgente gestión. Se proponen tres áreas o enfoques particulares para mejorar la comprensión y gestión de los ríos urbanos en Latinoamérica: (1) Los estudios deben centrarse desde la visión de cuenca, (2) Es necesario una comprensión de la función del ecosistema acuático y la identificación de los servicios ecosistémicos, para justificar la gestión y restauración, y finalmente, (3) Los modelos de pagos por servicios ambientales pueden ser una buena estrategia para gestionar proyectos de conservación y restauración en las cuencas altas de estos ríos urbanos.

Palabras clave: condiciones de calidad; conocimiento científico; ecosistema urbano; estrategias de gestión; suministro de agua.

\section{REFERENCES}

Akhmouch, A., Clavreul, D., \& Glas, P. (2018) Introducing the OECD Principles on Water Governance, Water International, 43:1, 5-12, DOI: 10.1080/02508060.2017.1407561

Alfaro, R., Barquero, K., Chacón, K., Durán, S., Gómez, S., González, V.,... Villarreal, E. (2017). Estado de la nación en desarrollo humano sostenible. Informe 23 San José: Servicios gráficos AC. Retrieved from http:// repositorio.conare.ac.cr/handle/20.500.12337/1118

Alfonso, W. \& Pardo, C. (2014). Urban material flow analysis: An approach for Bogotá, Colombia. Ecological Indicators, 42, 32-42. https://DOI.org/10.1016/j. ecolind.2013.10.035

Anim, D. O., Fletcher, T. D., Vietz, G. J., Burns, M. J., \& Pasternack, G. B. (2019). How alternative urban stream channel designs influence ecohydraulic conditions. Journal of Environmental Management, 247, 242-252. https://DOI.org/10.1016/j. jenvman.2019.06.095
Bezaury-Creel, J. E., Ochoa-Pineda, F., Llano-Blanco, M. O., Lasch-Thaler, C., Herron, C., Vázquez-Castañeda, D., \& Hernández-Ruíz, F. (2017). Agua dulce, conservación de la biodiversidad, protección de los servicios ambientales y restauración ecológica en México. The Nature Conservancy. Ciudad de México, México. DOI: 10.13140/RG.2.2.10282.31685

Bremer, L. L., Auerbach, D. A., Goldstein, J. H., Vogl, A. L., Shemie, D., Kroeger, T. \& Herron, C. (2016). One size does not fit all: Natural infrastructure investments within the Latin American Water Funds Partnership. Ecosystem Services, 17, 217-236. https:// DOI.org/10.1016/j.ecoser.2015.12.006

Bower, K. M. (2014). Water supply and sanitation of Costa Rica. Environmental Earth Sciences, 71(1), 107-123. https://DOI.org/10.1007/s12665-013-2416-x

Capps, K. A., Bentsen, C. N., \& Ramírez, A. (2016). Poverty, urbanization, and environmental degradation: urban streams in the developing world. Freshwater Science, 35(1), 429-435. DOI: 10.1086 / 684945

Chin, A. (2006). Urban transformation of river landscapes in a global context. Geomorphology 79:460-487. DOI: 10.1016 / j.geomorph.2006.06.033

Corcoran, E., C. Nellemann, E. Baker, R. Bos, D. Osborn, \& Savelli, H. (Eds). (2010). Sick Water? The central role of wastewater management in sustainable development. A Rapid Response Assessment. United Nations Environment Programme, ONU-HABITAT, GRID-Arendal.www.grida.no. Retrieved from https:// cld.bz/bookdata/vV8Z3Zt/basic-html/page-1.html

Da Cruz e Sousa, R. \& Ríos-Touma B. (2018). Stream restoration in Andean cities: learning from contrasting restoration approaches. Urban Ecosystems 21(2), 281-290. https://DOI.org/10.1007/ s11252-017-0714-x

De Jesús-Crespo, R. \& Ramírez, A. (2010). The use of a Stream Visual Assessment Protocol to determine ecosystem integrity in an urban watershed in Puerto Rico. Physics and Chemistry of the Earth, Parts $A / B / C$, 36(12), 560-566. DOI: $10.1016 / \mathrm{j}$. pce. 2010.11 .007

Engman, A.C., Ramírez, A. (2012). Fish assemblage structure in urban streams of Puerto Rico: the importance of reach- and catchment-scale abiotic factors. Hydrobiologia 693(1), 141-155. https://DOI.org/10.1007/ s10750-012-1100-6

Elmqvist T., Redman C.L., Barthel S., Costanza R. (2013) History of Urbanization and the Missing Ecology. In: Elmqvist T. et al. (Eds) Urbanization, Biodiversity and Ecosystem Services: Challenges and Opportunities. Springer, Dordrecht. DOI: https:// DOI.org/10.1007/978-94-007-7088-1_2

Ezquiaga Arquitectura, Sociedad y Territorio S.L. (2015). The Experience of Latin America and the 
Caribbean in Urbanization: Knowledge Sharing Forum on Development Experiences: Comparative Experiences of Korea and Latin America and the Caribbean. Retrieved from https://publications.iadb. org/publications/english/document/The-Experienceof-Latin-America-and-the-Caribbean-in-Urbanization-Knowledge-Sharing-Forum-on-DevelopmentExperiences-Comparative-Experiences-of-Koreaand-Latin-America-and-the-Caribbean.pdf

Fernandez, B. (2017). Clean water and sanitation for all: interactions with other sustainable development goals. Sustainable Water Resources Management 3(4), 479489. https://DOI.org/10.1007/s40899-017-0117-4

García-Sánchez, M., \& Güereca, L. P. (2019). Environmental and social life cycle assessment of urban water systems: The case of Mexico City. Science of The Total Environment, 693, 13344. https://DOI. org/10.1016/j.scitotenv.2019.07.270

Gutiérrez-Fonseca, P. E., \& Ramírez, A. (2016). Evaluación de la calidad ecológica de los ríos en Puerto Rico: principales amenazas y herramientas de evaluación. Hidrobiológica, 26(3), 433-441. DOI: https:// DOI.org/10.24275/uam/izt/dcbs/hidro/2016v26n3

Kaushal, S. S., Gold, A. J., Bernal, S., Johnson, T. A. N., Addy, K., Burgin, A., ...\& Kenneth, T.B. (2018). Watershed 'chemical cocktails': forming novel elemental combinations in Anthropocene fresh waters. Biogeochemistry, 141(3), 281-305. https://DOI org/10.1007/s10533-018-0502-6

Koop, S. H., \& van Leeuwen, C. J. (2017). The challenges of water, waste and climate change in cities. Environment, Development and Sustainability, 19(2), 385418. https://DOI.org/10.1007/s10668-016-9760-4

Lee, T. R. (2000). Urban water management for better urban life in Latin America. Urban Water, 2(1), 71-78. https://DOI.org/10.1016/S1462-0758(00)00041-8

Lepori, F., D. Palm \& B. Malmqvist. (2005). Effects of stream restoration on ecosystem functioning: detritus retentiveness and decomposition. Journal of Applied Ecology 42(2), 228-238 DOI:10.1111/j.1365-2664.2004.00965.x

Lugo, A. E., Ramos-González, O.M., \& RodríguezPedraza., C. (2011). The Rio Piedras Watershed and its surrounding environment. Vol FS-980. US Department of Agriculture, Forest Service. Retrieved from https://www.fs.fed.us/global/iitf/pubs/RioPiedras FNLrvsd.pdf

Martin-Ortega, J., Ojea, E., \& Roux, C. (2013). Payments for water ecosystem services in Latin America: a literature review and conceptual model. Ecosystem Services, 6, 122-132. https://DOI.org/10.1016/j. ecoser.2013.09.008

Manrique-Hernández, H., Heartsill-Scalley, T., BarretoOrta, M., Betancourt-Román, C., \& Ortiz-Zayas, J.
(2016). Assessing Restoration Outcomes in Light of Succession: Management Implications for Tropical Riparian Forest Restoration. Ecological Restoration 34(2),147-158. DOI: 10.3368 / er.34.2.147

McDonald, R.I. \& D. Shemie. (2014). Urban Water Blueprint: Mapping conservation solutions to the global water challenge. The Nature Conservancy: Washington, D.C. Retrieved from http:/water. nature.org/waterblueprint/\#/section=overview $\& c=3:-22.10600:-82.70508$

McDonald, R. I., Weber, K., Padowski, J., Flörke, M., Schneider, C., Green, P. A., ...\& Montgomeryi, M. (2014). Water on an urban planet: Urbanization and the reach of urban water infrastructure. Global Environmental Change, 27, 96-105. https://DOI. org/10.1016/j.gloenvcha.2014.04.022

McDonald, R. I., Douglas, I., Revenga, C., Hale, R., Grimm, N., Grönwall, J., \& Fekete, B. (2011). Global urban growth and the geography of water availability, quality, and delivery. Ambio, 40(5), 437-446. https:// DOI.org/10.1007/s13280-011-0152-6

Mena-Rivera, L., Vásquez-Bolaños, O., Gómez-Castro, C., Fonseca-Sánchez, A., Rodríguez-Rodríguez, A., \& Sánchez-Gutiérrez, R. (2018). Ecosystemic Assessment of Surface Water Quality in the Virilla River: Towards Sanitation Processes in Costa Rica. Water, 10(7), 845-861. https://DOI.org/10.3390/ w10070845

Montgomery, M. A., \& Elimelech, M. (2007). Water and sanitation in developing countries: including health in the equation. Environmental Science and Technology, 41, 17-24. https://DOI.org/10.1021/es072435t

Noyola, A., Padilla-Rivera, A., Morgan-Sagastume, J. M., Güereca, L. P., \& Hernández-Padilla, F. (2012). Typology of municipal wastewater treatment technologies in Latin America. Clean-Soil, Air, Water, 40(9), 926932. https://DOI.org/10.1002/clen.201100707

Paul, M. J., \& Meyer, J. L. (2001). Streams in the urban landscape. Annual Review of Ecology and Systematics 32, 333-365. https://DOI.org/10.1146/annurev. ecolsys.32.081501.114040

Peña Guzmán, C. A., Melgarejo Moreno, J., \& Prats Rico, D. (2016). El ciclo urbano del agua en Bogotá, Colombia: estado actual y desafíos para la sostenibilidad. Tecnología y Ciencias del Agua, 7(6), 57-71. DOI: http://www.revistatyca.org.mx/ojs/index.php/ tyca/article/view/1282

Ramírez, A., De Jesús-Crespo, R., Martinó-Cardona, D. M., Martínez-Rivera, N., \& Burgos-Caraballo, S. (2009). Urban streams in Puerto Rico: what can we learn from the tropics? Journal of the North American Benthological Society, 28(4), 1070-1079. https:// DOI.org/10.1899/08-165.1 
Ramírez, A., Pringle, C. M., \& Wantzen, K. M. (2008) Tropical stream conservation. In Tropical stream ecology (pp. 285-304). Academic Press. https://DOI. org/10.1016/B978-012088449-0.50012-1

Ramírez-Sánchez, I. M., Doll, S., \& Bandala, E. R. (2015). Drinking Water and Sanitation in Central America: Challenges, Perspectives, and Alternative Water Treatment. In Water Challenges and Solutions on a Global Scale (pp. 53-70). American Chemical Society. DOI: 10.1021 / bk-2015-1206.ch004

Ríos-Touma, B. \& A. Ramírez. (2019). Multiple Stressors in the Neotropical Region: Environmental Impacts in biodiversity hotspots. In: S. Sabater, A. Elosegi, \& R. Ludwig (Eds). Multiple Stressors in River Ecosystems. Elsevier, Cambridge, MA. https://DOI. org/10.1016/B978-0-12-811713-2.00012-1

Rodríguez, J. P., Díaz-Granados, M., Camacho, L. A., Raciny, I. C., Maksimovic, C., \& McIntyre, N. (2008). Bogotá's urban drainage system: Context, research activities and perspectives. In BHS 10th National Hydrology Symposium, Exeter. Retrieved from https:// www.researchgate.net/profile/Neil_Mcintyre3/publication/230887914 Bogota's urban drainage system context research activities and perspectives/ links/0f3175398fa0940e34000000/Bogotas-urbandrainage-system-context-research-activities-andperspectives.pdf

Rodríguez, J., \& Martine, G. (2008). Urbanization in Latin America and the Caribbean: experiences and lessons learned. The new global frontier: urbanization, poverty and environment in the 21st century, 353367. Retrieved from http://www.untag-smd.ac.id/ files/Perpustakaan_Digital_1/ENVIRONMENT\%20 The $\% 20$ new $\% 20$ global $\% 20$ frontier $\% 20 \% 20$ urbanization, $\% 20$ poverty $\% 20$ and $\% 20$ environment $\% 20$ in $\% 20$ the $\% 2021 \mathrm{st} \% 20$ century.pdf

Rodríguez, D. J., Serrano, H. A., Delgado, A., Nolasco, D., \& Saltiel, G. (2020). From Waste to Resource: Shifting Paradigms for Smarter Wastewater Interventions in Latin America and the Caribbean. World Bank, World Bank, Washington, DC. Water Papers. https:// DOI.org/10.1596/33436

Romulo, C. L., Posner, S., Cousins, S., Fair, J. H., Bennett, D. E., Huber-Stearns, H., ... \& McDonald, R. I. (2018). Global state and potential scope of investments in watershed services for large cities. Nature Communications, 9(1), 1-10. DOI: https://DOI. org/10.1038/s41467-018-06538-x
Roni, P., Hanson, K., \& Beechie, T. (2008). Global review of the physical and biological effectiveness of stream habitat rehabilitation techniques. North American Journal of Fisheries Management, 28(3), 856-890. https://DOI.org/10.1577/M06-169.1

Roy, A. H., Capps, K. A., El-Sabaawi, R. W., Jones, K. L., Parr, T. B., Ramírez, A., ... \& Wenger, S. J. (2016). Urbanization and stream ecology: diverse mechanisms of change. Freshwater Science, 35(1), 272277. DOI: $10.1086 / 685097$.

Seto, K. C., Parnell, S., \& Elmqvist, T. (2013). A global outlook on urbanization. In Urbanization, biodiversity and ecosystem services: Challenges and Opportunities (pp. 1-12). Springer, Dordrecht. DOI: 10.1007/978-94-007-7088-1

Tellman, B., McDonald, R. I., Goldstein, J. H., Vogl, A. L., Flörke, M., Shemie, D., ... \& Veigal, F. (2018). Opportunities for natural infrastructure to improve urban water security in Latin America. PloS ONE, 13(12). https://DOI.org/10.1371/journal. pone. 0209470

United Nations-UN, Department of Economic and Social Affairs, Population Division (2019). Revision of World Population Prospects. Online. Retrieved from https://population.un.org/wpp/

Vörösmarty, C., McIntyre, P. B., Gessner, M., Dudgeon, D., Prusevich, A., Green, P., ...\& Davies, P. M. (2010). Global threats to human water security and river biodiversity. Nature 467, 555-561. https://DOI. org/10.1038/nature09440

Vörösmarty, C. J., Lévêque, C., \& Revenga, C. (2005). Fresh Water. Ch. 7 In: R. M. Hassan, R. Scholes, \& N. Ash (Eds). Ecosystems and Human Wellbeing: Current State and Trends Millennium Ecosystem Assessment, USA. Retrieved from https:// www.millenniumassessment.org/documents/document.276.aspx.pdf

Wade, J. S. (2012). The future of urban water services in Latin America. Bulletin of Latin American Research, 31(2), 207-221. DOI: 10.1111/j.1470-9856.2011.00603.x

Walsh, C. J., Roy, A. H., Feminella, J. W., Cottingham, P. D., Groffman, P. M., \& Morgan, R. P. (2005). The urban stream syndrome: current knowledge and the search for a cure. Freshwater Science, 24(3):706-723. https://DOI.org/10.1899/04-028.1 


\section{APPENDIX 1}

Questions included in the survey.

\section{Introducción}

Por río urbano entiéndase el segmento del río que cruza la ciudad, excluyendo las cabeceras si estas no son urbanas. Si está familiarizado con más de un río urbano, responda pensando en la condición promedio.

\section{Información sobre el río elegido}

1. ¿Cuál es su ciudad?

2. ¿Cuál es su país?

3. ¿Cuál es la población aproximada de esta ciudad?

4. ¿Cuál es el estado de los ríos urbanos en su ciudad?

a. Algo impactados, pero mantienen su carácter de ecosistema (con vegetación ribereña y cauce natural)

b. Impactados, mezcla de cauces naturales y completa canalización

c. Completamente canalizados en concreto o piedra, como canales de drenaje

5. ¿Qué tanta contaminación recibe?
a. Poca, mayormente escorrentías de las calles
b. Media, escorrentías y descargas de industrias y casas
c. Alta, escorrentías y aguas negras. Mal olor evidente

6. ¿Cuál es la estrategia predominante de manejo de aguas negras en su ciudad?

a. Sistema municipal de recogido de aguas negras, entubadas para ser descargadas en una planta de tratamiento

b. Sistema municipal de recogido de aguas negras, entubadas y descargadas sin mayor tratamiento lejos de la ciudad

c. Sistema municipal de recogido de aguas negras, entubadas y descargadas sin mayor tratamiento a ríos dentro de la ciudad

d. Mayormente tanques sépticos

7. ¿Cuál es la estrategia dominante de manejo de aguas de lluvia?
a. Ninguna, el agua drena a los ríos directamente sin entubarse, por los drenajes de las calles
b. Se recogen, entuban, y descargan a los ríos eventualmente
c. Se combinan los sistemas de recogido de aguas de lluvia con los de aguas negras
d. Se trasladan a charcas de retención u otro método de manejo
e. Otro

8. ¿Es la falta de información sobre el ecosistema una limitante para el manejo de ríos urbanos?
a. No, solo es falta de voluntad política y fondos
b. Si, falta información sobre el funcionamiento del río
c. $\mathrm{Si}$, falta información sobre el valor del río y los servicios que provee
d. Otro 
9. ¿Qué visión tienen las personas y políticos sobre los ríos urbanos?
a. Son potenciales peligros debido a asuntos de seguridad
b. Son potenciales peligros debido a las inundaciones
c. Son potenciales zonas de recreación
d. Otro

10. ¿Qué tipo de uso le dan a los ríos urbanos?
a. Recreación
b. Pesca
c. Fuente de agua
d. Descarga de agua y basura
e. Extracción de material (piedra, arena)
f. Otro

11. ¿Conoce de alguna ley dirigida a la protección de los ríos urbanos?

12. ¿Existe algún control sobre las descargas a los ríos? ¿Se tramitan permisos para hacer descargas a los ríos urbanos?

13. ¿Qué tipo de información ecológica existe sobre los ríos urbanos?
a. Se conoce la flora y fauna nativa y exótica
b. Se conoce sobre la diversidad
c. Se conoce sobre el funcionamiento del ecosistema
d. No se sabe nada

14. ¿Existen acciones de manejo, protección o restauración de ríos urbanos?

\section{Información sobre quien completa el formulario}

15. Cargo o puesto
a. Investigador
b. Profesor
c. Estudiante
d. Técnico
e. Otro

16. Nombre y Apellidos (Opcional)

17. Correo electrónico (Opcional)

18. Afiliación (Opcional) 